\title{
Diastereoselective [4+4] Cycloadditions
}

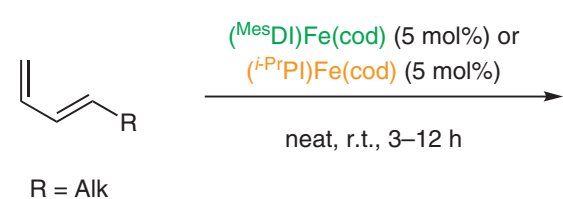

$\mathrm{R}=$ Alk

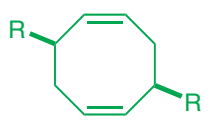

A

\section{Category}

Metals in Synthesis

\section{Key words}

cycloaddition

diastereoselectivity

iron catalysis

Selected examples:

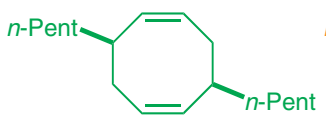

$89 \%$ yield

$\mathrm{A}: \mathrm{B}=93: 7$

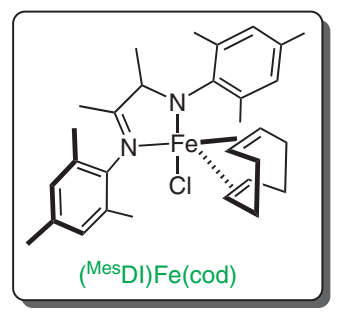

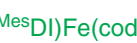

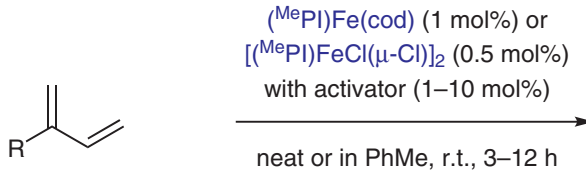

activator $=\mathrm{Mg}\left(\mathrm{C}_{4} \mathrm{H}_{6}\right) \cdot 2 \mathrm{THF}, \mathrm{MeMgCl}$ or $\mathrm{Mg}$

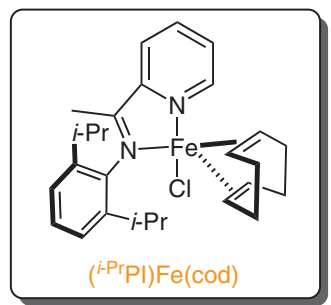

(MepI)Fe(cod) (1 mol\%) or $\left[\left({ }^{\mathrm{Me}} \mathrm{PI}\right) \mathrm{FeCl}(\mu-\mathrm{Cl})\right]_{2}(0.5 \mathrm{~mol} \%)$

neat or in PhMe, r.t., 3-12 h

$$
\mathrm{R}=\mathrm{Alk}
$$

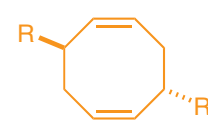

B

Selected examples:

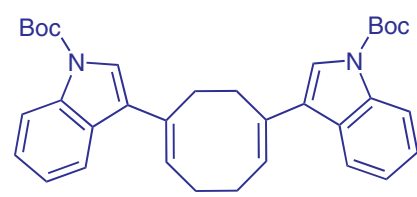

$90 \%$ yield

C: $:$ = 94:6

(Mepl)Fe(cod) was used<smiles>O=C(CC/C1=C/CC/C=C(/CCC(=O)N2CCCCC2)CC1)N1CCCCC1</smiles>

$100 \%$ yield

$$
\text { C:D = 95:5 }
$$

$\left[\left({ }^{\mathrm{Me}} \mathrm{PI}\right) \mathrm{FeCl}(\mu-\mathrm{Cl})\right]_{2}$ was used
Significance: Chirik and co-workers report a regio- and diastereoselective iron-catalyzed [4+4] cycloaddition of 1,3-dienes, leading to various substituted cyclooctadienes in excellent yields.
Comment: Remarkably, with the choice of the iron catalyst, the cyclodimerization can be controlled in a diastereoselective fashion. Extensive mechanistic studies were performed and catalytically relevant iron complexes were isolated and characterized. 